\title{
Four Ways of Fine Motor Skills Development in Early Childhood
}

\author{
Syafrimen Syafril ${ }^{1, *}$, Ria Susanti $^{1}$, Rifda El Fiah ${ }^{1}$, Titik Rahayu ${ }^{2}$, Agus Pahrudin ${ }^{1}$, Nova \\ Erlina Yaumas ${ }^{1,2}$, Noriah Mohd. Ishak ${ }^{2}$ \\ ${ }^{1}$ Universitas Islam Negeri Raden Intan Lampung, Indonesia \\ ${ }^{2}$ Fakulty of Education, Universiti Kebangsaan Malaysia, 43600 UKM Bangi, Selangor, \\ Malaysia \\ *Corresponding author: syafrimen@radenintan.ac.id
}

Tel.: +6281374576227

Fax: +62 721780887

\begin{abstract}
Fine motor skill is the ability to control movement through activities coordination of nervous system, fibril, and muscles such as fingers and hands. Fine motor skill is also seen as a very important factor in the process of developing cognitive abilities in early childhood. This study aims to see how to develop fine motor skills in early childhood. The study was conducted using a qualitative descriptive approach (multi case single site case study design) involving 2 teachers. Data were collected through observation and interviews, then analyzed thematically using NVIVO 10 software. The results showed that fine motor skill development was carried out using the method of assignment in four ways: (i) Providing tools and materials, (ii)
\end{abstract}


providing direction and opportunities for practice, (iii) observe children individually and in groups, (iv) evaluate their fine motor skill development on an ongoing basis. This study shows that these four ways can be used as an alternative in developing fine motor skill in early childhood.

Keywords : Fine motor skills development, assignment, multi case single site, early childhood

\section{Introduction}

Fine motor skills are one of the important components in children's activities at school. About $30-60 \%$ of the day, the teacher needs to provide motoric tasks to the children in school, where understanding motor skills can help improve students' abilities in the academic field (ChinKai Lin, 2014). At the age of 3 years, children have the ability to grab objects with thumb and index finger, at the age of 4 years the fine motoric in children has begun to develop, such as building high towers with bricks toys, in 5 years old the child's motor skills will have developed to a much higher degree, fingers, arms, and hands all moving under the eye-hand coordination, and 6 years old children can tying shoelaces, and dressing up (James K. H \& Engelhardt L, 2012; James, 2010; Santrock, 2007; Wilhelm I. Prehn-Kristensen A \& Born J, 2012). Fine motor skills development deals with the manipulation of manual objects, such as writing, weaving ropes, arranging beams, tying shoelaces, flipping pages of books, cutting with scissors, playing dough, and making shapes from folding paper (Amel E Abdel Karim, 2015; Houwen, 2009; Laura, 2013; Mayes S D, 2009; Xia Wei, 2016). In addition, fine motor skills can be activities such as cutting with scissors, coloring, drawing with pencils and crayons (Punum Bhatia Alan Davis \& Ellen Shamas-Brandt et al, 2015). Thus, the teacher needs to understand the children fine motor skills development while in school. Fine motor 
skill is the ability to control movement through coordinated activities of the nervous system and muscles such as the movements of fingers and hands (McPhillips \& Jordan-Black, 2007). According to McPhillips and Jordan-Black (2007) Fine motor skills in kindergarten must be in accordance with the curriculum measured through developmental tasks with the achievement indicators, and in accordance with the standards of early childhood education. Children's fine motor skills development indicators can be designed for one year (L. S. Pagani, Fitzpatrick, C., Archambault, I., \& Janosz,M. , 2010). Some studies highlight the role of fine motor skill in cognitive and mathematical development (D. Grissmer, Grimm, K. J., Aiyer, S. M., Murrah, W. M., \& Steele, J. S, 2010; Luo, 2007; L. S. Pagani, Fitzpatrick, C., Archambault, I., \& Janosz, M, 2010), the roles of fine motor skills are also examined in relation to reading and literacy development (Brookman, 2013; Cameron, 2012; D. Grissmer, Grimm, K. J., Aiyer, S. M., Murrah, W. M., \& Steele, J. S, 2010). An example of how to develop a child's fine motor skill is with holding and placing beads on the stem (Piek, 2008; Rigoli, 2012), cut and write quickly and clearly (Tseng, 2010; Wilson, 2009). This can be done by children, because in the early days children experienced a period of rapid growth and learning (Suzanne Houwen, 2016). Fine motor skills development in early childhood allows them to explore, play, and manipulate objects or tools in their daily activities (Henderson, 2006).

Low physical activity on motor skills can give an impact on the development of children's motor skills (Hurter Z \& Pienaar E, 2007; Malina R M, 2012). The teacher needs to take various approaches so the children can be active and confident in the movement, and the child has a higher participation in the fine motor skills development process (Robinson L E, 2011; Robinson L E \& Goodway J D, 2009; Robinson L E Reynolds J Wadsworth \& Logan, 2010). Some studies have found that physical activity is very important in developing children's motor skills (Gallahue D L \& Ozmun J C, 2006; Harvey W J \& Mcgill U, 2007), 
precisely the child must be physically active to develop new motor skills through motor movements (Pienaar, 2016). Fine motor skills are very important in the early development of children (D. W. Grissmer, Grimm, K. J., Aiyer, S. M., Murrah, W. M., \& Steele, J. S. , 2010). So, the teachers need to provide opportunities for children to practice spontaneously with various materials, because the success of children in school is related to the coordination of several skills (Pianta, 2007).

The study showed that teachers were not fully prepared to carry out activities to develop quality fine motor skills for early childhood (Breslin, 2008). Teachers should be able to use various methods to support children's fine motor skills development activities (Santos O C \& Boticario J G, 2011), because the use of this method can improve fine motor skills, and affect children's development (Ni Luh Ami Yestiari, 2014; Ni Wayan Yuni Sudiasih, 2014). One method that can be used in developing children's fine motor skill is the method of assignment, this method can improve the effectiveness and efficiency of development activities (D. Made Dwi Purnama Sari, 2015), and stimulate children in carrying out activities (Hodel, 2014 ; Janacsek, 2012; Savion-Lemieux, 2009; Wilhelm, 2008). Some studies show that the method of giving assignments can motivate the children to be active, both individually and in groups (Ni Made Ayu Aristyadewi, 2015). According to Made Dwi Purnama Sari (2015) assignment method is useful to improve fine motor and gross motor skills, introducing mathematical concepts such as knowing weight and light, long and short, big and small, high and low, classifying objects based on colors and shapes, studying differences in geometric shapes, and stimulating creativity and imagination of child.

Based on the review above, it can be seen that developing fine motor skills in early childhood is very important to improve their cognitive abilities. This study tries to see how to develop fine motor skills in early childhood. 


\section{Methodology}

The study was conducted using a qualitative approach with the type of case study research design (multi-case single-site case study design) (Yin, 2008a, 2013). The use of this type of research allows researchers to get a variety of information related to the problems studied (Creswell J W, 2007, 2014, 2015; Yin R K, 2008, 2013). Data was collected through observation and interviews with two teachers who carried out the process of fine motor skills development in early childhood. Data analyzed with qualitative "thematically" aided by NVIVO 10 software (Yin, 2008b).

\section{Finding and Discussion}

The results showed that fine motor skills development was carried out using the assignment method through four ways: (i) Providing tools and materials, (ii) providing direction and opportunities for children to practice, (iii) observing children individually and in groups, (iv ) always evaluate the child's fine motor skills development on an ongoing basis. Examples of teacher responses through interviews conducted are as follows:

Subject $1 \quad: \ldots \ldots$ we always prepare the media in carrying out the activities, but before implementing fine motor skills development activities, i give direction on how to use the media, so the child's fine motor skills can be stimulated properly. Furthermore, to evaluate children's activities, i provide opportunities for children to try to do the activities described earlier.

Subject $2 \quad:$...... we always observe children during activities, both individually and in groups. In the implementation of our activities we do not discriminate between the work of the child's fine motor skills with each other. However, we always evaluate the children's work so we can see the results of the child's fine motor 
skills development.

Several studies have shown that fine motor skills are one of the initial activities in early childhood education (Brown, 2010; Cameron C E Brock, 2012; Carlson, 2013; Duncan, 2007; D. W. Grissmer, Grimm, K. J., Aiyer, S. M., Murrah, W. M., \& Steele, J. S. , 2010). Fine motor skills show children's creativity (McClelland, 2011). The child's movement and physical activity are related to the child's quality of life (Piek J P Dawson L Smith L M \& Gasson N, 2008). Research Clark (2007) find children can do movement activities through interaction with their environment, such as through the activity of folding paper, drawing, and cutting (Markovic Z \& Kopas-Vuka sinovic V, 2012; Ziviani J Poulsen A \& Hansen C, 2009). The results from previous studies are in line with this study which found that children's fine motor skills development through four ways of assignment method carried out by the teacher is actually possible to be able to assist fine motor skills development in early childhood.

Fine motor activities shows a positive relationship with children's physical activity (Kalaja S Jaakkola T Liukkonen J \& Watt A, 2010; Lubans et al, 2010; Stodden, 2010). Providing tools and materials, giving direction and giving the children opportunity to practice in the process of fine motor skills development by the teacher as shown in this study is one of the physical activities. This illustrates that the process of development carried out by the teacher shown by this study is in line with the findings of several studies. Some previous studies also found that the most commonly used approach to children's fine motor skills development is writing activities (Dayan E \& Cohen L G, 2011; Wilhelm I. Prehn-Kristensen A \& Born J, 2012). Writing activity is clearly a physical activity that gives children the full opportunity to express their fine motor skills through holding, how to draw stationery, or in the process of doing the graffiti. Through indirect writing activities the teacher can observe 
the fine motor skills development of children individually or in groups. At the same time can make a continuous evaluation of the fine motor skills development of children as explained in this study.

Fine motor development is not only from writing motion, but many activities that can support fine motor skills development, such as; (i) describe the concepts of underlying skills, (ii) provide guidance and explanations about skills, (iii) present explicitly the phase of skills, (iv) focusing children's attention on skills, (v) provide direction, (vi) provide broad opportunities for practice, (vii) spur the motivation of children to be actively involved in development activities that carried out (Lim W Y \& Koh M, 2006; Mohnsen B, 2008). These findings are in line with the results of this study that the way of fine motor development carried out by the teacher actually refers to the findings of the study as described, namely providing guidance and providing the widest possible practice opportunities, provide appropriate direction and guidance and provide motivation so that children are always actively involved in the development process. The way of development carried out by the teacher is a form of teacher empathy for children in the education process (Syafrimen, 2017a). Indeed, this method can increase children's motivation in the process of fine motor skills development.

Studies about children's motivation have also been alluded to earlier by the reviewers, that teachers need to provide motivation in improving business, competencies and skills (Patall E A Cooper H \& Robinson J C, 2008), then motivation is carried out repeatedly and continuously (Brown R M \& Robertson E M, 2007). This is to increase the child's potential gradually (Censor N Sagi D \& Cohen LG, 2012a). Syafrimen (2017b) states that the development of children's potential can be done by providing support and encouragement, opening opportunities, and providing awareness. In line with the results of this study which 
found that in developing children's fine motor skills, teachers need to provide direction and provide opportunities for children to practice activities carried out during school. In addition, the teacher needs to improve the child's fine motor skills gradually, and evaluate the child's fine motor skills development that has been achieved (Atasoy, 2006; Censor N Sagi D \& Cohen LG, 2012b; Dorfberger S Adi-Japha E \& Karni A, 2007, 2014). In the process of developing the teacher is also required to be fully aware of the different fine motor skills of each child (Leah E, 2012). Some experts find that boys tend to be more advanced than girls (Barnett L M van Beurden et al, 2009; Walter C, 2011). The reviewer agreed with several studies, because one of the steps for children's fine motor skills development is the way teachers observe children individually and in groups, and constantly evaluate the child's fine motor development on an ongoing basis.

Individual, task, and environmental interactions influence the development of children's motor skills (Shumway-Cook, 2007), so that teachers need to provide opportunities for children to always learn from their environment (Adolph, 2007; Von Hofsten, 2009). This is in line with one of the methods of children's fine motor development from the results of this study, namely by providing full opportunities to children through guidance and guidance from the teacher in the process of children's fine motor development. When the fine motor development process is carried out, the child needs maximum guidance from the teacher (Lieberman J \& Breazeal, 2007), and the teacher can choose various methods that are appropriate for the child's fine motor skills development process (Portillo-Rodriguez, 2008). Klassen (2011) states that among the development methods that can be used by teachers are (i) verbal instruction, (ii) guiding children's physical movements, and (iii) exploring through visuals by showing movement and the children imitating the movements shown by the teacher. In line with these findings, other views state that for the maximum development of 
each child must move his body to achieve the goal of fine motor skills development (Olga C Santos, 2016). Marina Papastergiou (2014) explained that fine motor skills involves a certain parts of a person's body such as hands, motor skills involve the movement of the whole body in coordination with external stimuli. In line with the results of this study that the teacher provides direction to the children in the process of fine motor skills development. This illustrates that the development process undertaken by the teacher is in line with the various development processes put forward by various studies before.

\section{Conclusion}

Fine motor skills development is very important for early childhood to ensure their willingness to enter the next level of education. Four ways of fine motor skills development through assignment methods can be used as an alternative in the process of fine motor skills development in early childhood. Finding various alternatives in the process of fine motor skills development in early childhood is one form the teacher's seriousness and professionalism in the process of early childhood motoric development.

\section{References}

Adolph, K. E., \& Joh,A.S. (2007). Motor development: How infants get into the act. In A. Slater \& M. Lewis (Eds.), Introduction to infant development (2 ed.). New York,NY: Oxford University Press.

Amel E Abdel Karim, A. H. M. (2015). Effectiveness of sensory integration program in motor skills in children with autism. The Egyptian Journal of Medical Human Genetics, 16, 375-380.

Atasoy, S. v. A., A.R. (2006). Yapılandırmacı ogrenme kuramına gore gelistirilen calısma yapraklarının uygulama surecinin degerlendirilmesi. Milli Egitim Dergisi, 170, 157175.

Barnett L M van Beurden et al. (2009). Childhood motor skill proficiency as a predictor of adolescent physical activity. Journal of Adolescent Health, 44, 252-259.

Breslin, C. M., Morton, J. R., \& Rudisill, M. E. (2008). Implementing a physical activity curriculum into the school day: Helping early childhood teachers meet the challenge. 
Journal Early Childhood Education, 35, 429-437.

Brookman, A., McDonald, S., McDonald, D., \& Bishop, D. V. (2013). Fine motor deficits in reading disability and language impairment. Same or different? Peer J, 1(217).

Brown, C. G. (2010). Improving fine motor skills in young children: An intervention study. Educational Psychology in Practice, 26, 269-278.

Brown R M \& Robertson E M. (2007). "Off-line processing: Reciprocal interactions between declarative and procedural memories. Journal of Neuroscience, 27, 10468-10475.

Cameron C E Brock, L. G., Murrah, W. R., Bell, L., Worzalla, S., Grissmer, D. W., \& Morrison F J. (2012). Fine motor skills and executive function both contribute to kindergarten achievement. Child Development, 83, 1229-1244.

Cameron, C. E., Brock, L. L., Murrah, W. M., Bell, L. H., Worzalla, S. L., Grissmer, D., et al. (2012). Fine motor skills and executive function both contribute to kindergarten achievement. Child Development, 83, 1229-1244.

Carlson, A. G., Rowe, E. W., \& Curby, T. W. (2013). Disentangling fine motor skills' relation to academic achievement: The differential impact of visual-spatial integration and visual motor coordination. Journal of Genetic Psychology, 175(514-533).

Censor N Sagi D \& Cohen LG. (2012a). Commonmechanisms of human perceptual and motor learning. Nature Reviews Neuroscience, 13, 658-664.

Censor N Sagi D \& Cohen LG. (2012b). Commonmechanisms of human perceptual and motor learning. Nature Reviews Neuroscience, 13, 658-664.

Chin-Kai Lin, L.-F. M., Ya-Wen Yu, Che-Kuo Chen, Kuan-Hua Li. (2014). Factor analysis of the Contextual Fine Motor Questionnaire in Children. Research in Developmental Disabilities, 35, 512-519.

Clark, J. E. (2007). On the problem of motor skill development. Journal of Physical Education Recreation \& Dance, 78(5), 39-44.

Creswell J W. (2007). Research design: qualitative and quantitave approaches. Thousand Oaks, SAGE Publication.

Creswell J W. (2014). Research design: qualitative and quantitave approaches. Thausand Oaks, SAGE Publication.

Creswell J W. (2015). Research design: qualitative and quantitave approaches. Thousand Oaks, SAGE Publication.

Dayan E \& Cohen L G. (2011). Neuroplasticity subserving motor skill learning. Neuron, 72, 443-454.

Dorfberger S Adi-Japha E \& Karni A. (2007). Reduced susceptibility to interference in the consolidation of motor memory before adolescence. PLoS ONE, 2, e240.

Dorfberger S Adi-Japha E \& Karni A. (2014). Reduced susceptibility to interference in the consolidation of motor memory before adolescence. PLOS ONE, 2, e240.

Duncan, G., Dowsett, C. J., Claessens, A., Magnuson, K., Huston, A. C., Klebanov, P, Japel, C. (2007). School readiness and later achievement. Developmental Psychology, 43, 1428-1446. .

Gallahue D L \& Ozmun J C. (2006). Understanding motor development. Infants, children, adolescents, adults (6th ed.). NY: McGraw-Hill.

Grissmer, D., Grimm, K. J., Aiyer, S. M., Murrah, W. M., \& Steele, J. S. (2010). Fine motor skills and early comprehension of the world: Two new school readiness indicators. Developmental Psychology, 46, 1008-1017.

Grissmer, D. W., Grimm, K. J., Aiyer, S. M., Murrah, W. M., \& Steele, J. S. . (2010). Fine motor skills and early comprehension of the world: Two new school readiness indicators. Developmental Psychology, 46, 1008-1017.

Harvey W J \& Mcgill U. (2007). Fundamental movement skills and associated physical 
activity experiences of children with ADHD. Humanities and Social Sciences, 68(3), 927- 932.

Henderson, A., \& Pehoski, C. (2006). Hand function in the child: Foundations for remediation. St. Louis, MO Mosby Elsevier.

Hodel, A. S., Markant, J. C., Van Den Heuvel, S. E., Cirilli-Raether, J. M., \& Thomas, K. M. (2014 ). Developmental differences in effects of task pacing on implicit sequence learning. Frontiers in Psychology, 5, 153.

Houwen, S., Visscher, C., Koen, A. P. M., \& Lemmink, E. H. (2009). Motor skill performance of children and adolescents with visual impairments: A review. Exceptional Children, 75, 464-492.

Hurter Z \& Pienaar E. (2007). Fisieke aktiwiteitsvlakke en patrone van dertien- tot vyftienjarige seuns in die Noordwes- Provinsie: THUSA-BANA-studie. SuidAfrikaanse Tydskrif vir Navorsing in Sport. Liggaamlike Opvoedkunde en Ontspanning, 29(2), 41-57.

James K. H \& Engelhardt L. (2012). The effects of handwriting experience on functional brain development in pre-literate children. Trends in Neuroscience and Education, 1, $32-42$.

James, K. H. (2010). Sensori-motor experience leads to changes in visual processing in the developing brain. Developmental Science, 13, 279-288.

Janacsek, K., Fiser, J., \& Nemeth, D. (2012). The best time to acquire newskills: Age-related differences in implicit sequence learning across the human lifespan. Developmental Science, 15, 596-505.

Kalaja S Jaakkola T Liukkonen J \& Watt A. (2010). Fundamental movement skills and motivational factors influencing engagement in physical activity. Perceptual andMotor Skills, 111(1), 115-128.

Klassen, R., Tze, V., Betts, S., Gordon, K. (2011). Teacher efficacy research 1998-2009: signs of progress or unfulfilled promise? Educational Psychology Review. 23(1), 2143. doi:http://dx.doi.org/10.1007/s10648-010-9141-8

Laura, D. L. M. (2013). Associations Between Low-Income Children's Fine Motor Skills in Preschool and Academic Performance in Second Grade. Early Education and Development, 24:2, 138-161.

Leah E, R. E., Kipling Webster S, Wood Logan W, Amarie Lucas Laura T, Barber. (2012). Teaching Practices that Promote Motor Skills in Early Childhood Settings. Early Childhood Educ, 40, 79-86.

Lieberman J \& Breazeal, C. (2007). IKL: development of a wearable vibrotactile feedback suit for improved human motor learning. IEEE Transactions on Robotics, 23(5), 919926.

Lim W Y \& Koh M. (2006). E-learning: new opportunities for teaching and learning in gymnastics. British Journal of Teaching Physical Education, 37(1), 22-25.

Lubans et al. (2010). Fundamental movement skills in children and adolescents: review of associated health benefits. Sports Medicine, 40(12), 1019-1035.

Luo, Z., Jose, P. E., Huntsinger, C. S., \& Pigott, T. D. (2007). Fine motor skills and mathematics achievement in East Asian American and European American kindergartners and first graders. British Journal of Developmental Psychology, 25, 595-614.

Made Dwi Purnama Sari. (2015). Penerapan Metode Pemberian Tugas Berbantuan Media Balok Untuk Meningkatkan Perkembangan Kognitif Anak. E-Journal Pg-Paud Universitas Pendidikan Ganesha, Volume 3 No 1, h, 4.

Made Dwi Purnama Sari, D. (2015). Penerapan Metode Pemberian Tugas Berbantuan Mediabalok Untuk Meningkatkan Perkembangan Kognitif Anak. E-Journal Pg-Paud 
Universitas Pendidikan Ganesha, Volume 3 No 1.

Malina R M. (2012). Movement proficiency in childhood: implications for physical activity and youth sport. Kinesiologia Slovenica, 18(3), 19-34.

Marina Papastergiou, E. P., Ioannis Theofylaktou and Konstantina Karadimou. (2014). Examining the potential of web-based multimedia to support complex fine motor skill learning: An empirical study. Educ Inf Technol, 19, 817-839.

Markovic Z \& Kopas-Vuka sinovic V. (2012). Organisation of physical activities as a precondition for quality development of motor abilities of school children. Croatian Journal of Education, 15(1), 129-152.

Mayes S D, C., S. L., Bixler, E. O., \& Zimmerman, D. N. (2009). IQ and neuropsychological predictors of academic achievement. Learning and Individual Differences, 19, 238241.

McClelland, M., \& Cameron, C. E. (2011). Self-regulation in early childhood: Improving conceptual clarity and develo ping ecologically valid measures. Child Development Perspectives, 6(2), 136-142.

McPhillips, \& Jordan-Black. (2007). The effect of social disadvantage on motor development in young children: A comparative study. Journal of Child Psychology and Psychiatry, $48,1214-1222$.

Mohnsen B. (2008). Using technology in physical education (6th ed.). Cerritos: Bonnie's Fitware.

Ni Luh Ami Yestiari, d. (2014). Penerapan Metode Pemberian Tugas Melalui Kegiatan Mencocok Berbantuan Media Gambar Untuk Meningkatkan Motorik Halus. $e$ Journal PG-PAUD Universitas Pendidikan Ganesha, Volume 2 No 1.

Ni Made Ayu Aristyadewi, d. (2015). Penerapan Metode Pemberian Tugas Melalui Kegiatan Menggambar Dekoratif Media Krayon Untuk Meningkatkan Kemampuan Motorik Halus. E-Journal Pg Paud Universitas Pendidikan Ganesha, Volume 3 No.1.

Ni Wayan Yuni Sudiasih, d. ( 2014). Penerapan Metode Pemberian Tugas Berbantuan Media Playdough Untuk Meningkatkan Kemampuan Motorik Halus. E-Journal Pg-Paud Universitas Pendidikan Ganesha, Volume 2 No 1.

Olga C Santos. (2016). Training the Body: The Potential of AIED to Support Personalized Motor Skills Learning. Int J Artif Intell Educ, 26, 730-755.

Pagani, L. S., Fitzpatrick, C., Archambault, I., \& Janosz, M. (2010). School readiness and later achievement: A French Canadian replication and extension. Developmental Psychology, 46, 984-994.

Pagani, L. S., Fitzpatrick, C., Archambault, I., \& Janosz,M. . (2010). School readiness and later achievement: A French Canadian replication and extension. Developmental Psychology, 46, 984-994.

Patall E A Cooper H \& Robinson J C. (2008). The effects of choice on intrinsic motivation and related outcomes: A metaanalysis of research findings. Psychological Bulletin, 134(2), 270-300.

Pianta, R. C., Cox, M. J., \& Snow, K. L. (2007). School readiness and the transition to kindergarten in the era of accountability. Baltimore: Brookes.

Piek J P Dawson L Smith L M \& Gasson N. (2008). The role of early fine and gross motor development on later motor and cognitive ability. Human Movement Science, 27, 668-681.

Piek, J. P., Dawson,L.,Smith,L.M.,\& Gasson,N. (2008). The role of early fine and gross motor developmenton later motor and cognitive ability. Human Movement Science, 27, 668-681.

Pienaar, L.-L. v. N. d. T. A. E. (2016). The correlation between motor proficiency and 
physical activity in Senior Phase learners in the. Potchefstroom area health sa gesondheid, 21, 348-355.

Portillo-Rodriguez, O., Sandoval-Gonzalez, O., Ruffaldi, E., Leonardi, R., Avizzano, C., \& Bergamasco, M. . (2008). Real-time gesture recognition, evaluation and feed-forward correction of a multimodal Tai-Chi platform. En LNCS,, 5270, 30-39.

Punum Bhatia Alan Davis \& Ellen Shamas-Brandt et al. (2015). Educational Gymnastics: The Effectiveness of Montessori Practical Life Activities in Developing Fine Motor Skills in Kindergartners. Early Education and Development, 26:4, 594-607.

Rigoli, D., Piek,J.P.,Kane,R.,\& Oosterlaan,J. (2012). An examination of there lationship between motor coordination and executive functionsin adolescents. Developmental Medicine \&Child Neurology, 54, 1025-1031.

Robinson L E. (2011). Effect of a mastery climate motor program on object control skills and perceived physical competence in preschoolers. Research Quarterly for Exercise and Sport, 82, 355-359.

Robinson L E \& Goodway J D. (2009). Instructional climates in preschool children who are at-risk. Part I: Object-control skill development. Research Quarterly for Exercise and Sport, 80, 533-542.

Robinson L E Reynolds J Wadsworth \& Logan. (2010). The effects of physical play instructional climates on physical activity in preschool-age children [Abstract]. Science and Sports, , 25, 4-13.

Santos O C \& Boticario J G. ( 2011). Requirements for semantic educational recommender systems in formal e-learning scenarios. Algorithms, 4, 131-154.

Santrock. (2007). Perkembangan Anak. Edisi Kesebelas, Jakarta: Pt Gelora Aksara Pratama, 216.

Savion-Lemieux, T., Bailey, J. A., \& Penhune, V. (2009). Developmental contributions to motor sequence learning. Experimental Brain Research, 195(293-306).

Shumway-Cook, A., \& Woollacott, M. H. (2007). Motor control: Translating research into clinical practice. Philadelphia, PA: Lippincott Williams \& Wilkins.

Stodden, D. F., Barett, L., Goodway, J. D., Foweather, L., \& Liverpool, J. (2010). he relationship between motor skill competence and physical activity: the path may not be straight. Journal of Sport and Exercise Psychology, 32, 56-89.

Suzanne Houwen, L., Annettevander Putten,Carla Vlaskamp. (2016). The interrelationships between motor,cognitive, and language developmentin children with and without intellectual and developmental disabilities. Research in Developmental Disabilities, 53-54(2016), 19-31.

Syafrimen, N. M. I., Nova Erlina. (2017a). Emotional Intelligence Profile of Prospective Teachers. Journal of Enginering and Applied Sciences, 12(7), 1677-1680.

Syafrimen, N. M. I., Nova Erlina. (2017b). Six Ways To Develop Empathy of Educators. Journal of Enginering and Applied Sciences, 12(7), 1687-1691.

Tseng, M. H., Fu, C. P., Wilson, B. N., \& Hu, F. C. (2010). Psychometric properties of a Chinese version of the Developmental Coordination Disorder Questionnaire in community-based children. Research in Developmental Disabilities, 31, 33-45.

Von Hofsten, C. (2009). Action, the foundation for cognitive development. Scandinavian Journal of Psychology, 50, 617-623.

Walter C. (2011). In-school physical activity patterns of primary school learners from disadvantaged schools in South Africa. African Journal for Physical,." Health Education Recreation and Dance, 17(4:2), 779e788.

Wilhelm, I., Diekelmann, S., \& Born, J. . (2008). Sleep in children improvesmemory performance on declarative but not procedural tasks. Learning and Memory, 15, 373377. 
Wilhelm I. Prehn-Kristensen A \& Born J. (2012). Sleep-dependent memory consolidationwhat can be learnt from children? . Neuroscience \& Biobehavioral Reviews,, 36, $1718-1728$.

Wilson, B. N., Crawford, S. G., Green, D., Roberts, G., Aylott, A., \& Kaplan, B. J. (2009). Psychometric properties of the revised Developmental Coordination Disorder Questionnaire. Journal of Physical and Occupational Therapy in Pediatrics, 29(2), 182-202.

Xia Wei. (2016). Research on the Boost of Development on Young Children's Fine Motor by Folk Games. International Education Studies, Vol. 9, No. 9, 1913-9039.

Yin R K. (2008). Case Study Research: Design and Method (Applied Social Research Methods. Illinois, Sage Publications, Inc.

Yin R K. (2013). Applications of case study research. Newbury Park. SAGE Publications.

Yin, R. K. (2008a). Case Study Research: Design and Method (Applied Social Research Methods). Illinois: Sage Publications, Inc.

Yin, R. K. (2008b). Case Study Research: Design and Method (Applied Social Research Methods). Illinois: Sage Publications, Inc.

Yin, R. K. (2013). Applications of case study research. Newbury Park, SAGE Publications.

Ziviani J Poulsen A \& Hansen C. (2009). Movement skills proficiency and physical activity: a case for engaging and coaching for health $(\mathrm{EACH}) \mathrm{eChild}$. Australian Occupational Therapy Journal, 56, 259-265. 